Article

\title{
Cytotoxic Cembranes from Indonesian Specimens of the Soft Coral Nephthea sp.
}

\author{
Hedi Indra Januar ${ }^{1,2}$, Ekowati Chasanah ${ }^{1,2}$, Cherie A. Motti ${ }^{2}$, Dianne M. Tapiolas ${ }^{2}$, \\ Catherine H. Liptrot ${ }^{2, \dagger}$ and Anthony D. Wright ${ }^{2,3, *}$
}

1 Indonesia Research Center for Marine and Fisheries Product Processing and Biotechnology, J1. KS Tubun Petamburan VI, Jakarta 10260, Indonesia; E-Mails: idjanuar@gmail.com (H.I.J.); ekowati_ch@yahoo.com (E.C.)

2 Australian Institute of Marine Science, PMB No. 3, Townsville MC, Townsville, 4810, Australia; E-Mails: c.motti@aims.gov.au (C.A.M.); d.tapiolas@aims.gov.au (D.M.T.)

3 University of Hawaii, College of Pharmacy, 34 Rainbow Drive, Hilo, HI 96720, USA

$\dagger$ Current address: James Cook University, Townsville, QLD 4811, Australia; E-Mail: catherine.liptrot@jcu.edu.au.

* Author to whom correspondence should be addressed; E-Mail: adwright@hawaii.edu; Tel.: +1-808-933-2866; Fax: +1-808-443-5903.

Received: 19 June 2010; in revised form: 6 July 2010 / Accepted: 9 July 2010 /

Published: 13 July 2010

\begin{abstract}
Methanol extracts of two specimens of the soft coral Nephthea sp. collected from the Seribu Islands, Indonesia, were active in an anticancer bioassay. One new (1) and four known diterpenes (2-5) based on the cembrane carbon skeleton were isolated from these extracts, as was arachidonic acid (8). The structures of all compounds were elucidated using NMR, including 1,1-ADEQUATE and 1D gradient selective NOESY where applicable to determine the relative stereochemistry. Spectroscopic data, including ${ }^{1} \mathrm{H}$ and ${ }^{13} \mathrm{C}$ NMR, UV, IR and optical rotations are reported when enough material was available and where this has not been done previously. Inhibition assays employing three cancer cell lines; SF-268 (CNS), MCF-7 (breast), and H460 (lung) were used to guide the isolation of all compounds.
\end{abstract}

Keywords: Indonesia; marine natural products; soft coral; Nephthea sp.; anticancer; NMR; cembrane 


\section{Introduction}

A large diversity of marine organisms have been shown to produce secondary metabolites as a means of defense [1-4], many of these compounds also possess interesting biological activities [5-7]. Soft corals are no exception [8-12]. Investigations of soft corals from Indonesian waters have been limited with only six such reports on six unrelated soft coral species [13-18], the first of these appearing in 1997 [13]. Since 2002 [15,16], aside from the research undertaken by Fattorusso et al. [17], Wang et al. [18], and the current authors [19-22], there is little work being done with soft corals from this region of the world, even though they are likely to be rich sources of biologically active secondary metabolites. The information presented here resulted from a formal cooperation between the Indonesia Research Center for Marine and Fisheries Product Processing and Biotechnology, and the Australian Institute of Marine Science (AIMS), funded by an AusAID PSLP Indonesia grant. The investigation of two Nephthea (Alcyonacea, Nephtheidae) species, whose methanol (MeOH) extracts exhibited anticancer properties, resulted in the isolation of a new cembrane 3,4-epoxy-nephthenol acetate (1) along with five known compounds: decaryiol (2), 15-hydroxy-cembrenene (3), 2-hydroxy-nephthenol (4), nephthenol (5) and arachidonic acid (8). This report describes the structural elucidation of (1) and clearly shows that soft corals of Indonesian origin have significant potential as sources of biologically active and drug development lead compounds.

\section{Results and Discussion}

Compound 1 was isolated as a yellow oil from Nephthea sp. specimen A. Mass spectrometric analysis of the compound showed it to have the molecular formula $\mathrm{C}_{22} \mathrm{H}_{36} \mathrm{O}_{3}$ and therefore have five double bond equivalents of unsaturation. From the ${ }^{1} \mathrm{H}$ and ${ }^{13} \mathrm{C} \mathrm{NMR}$ data of $\mathbf{1}$, it was evident that the molecule contained two $\mathrm{C}=\mathrm{C}$ double bonds $\left(\delta_{\mathrm{C}} 123.6 \mathrm{~d}, 126.2 \mathrm{~d}, 132.4 \mathrm{~s}, 134.9 \mathrm{~s}\right)$ and one $\mathrm{C}=\mathrm{O}$ $\left(\delta_{\mathrm{C}} 170.2 \mathrm{~s}\right)$ double bond as the only multiple bonds establishing it as bicyclic. The 1D and 2D NMR data of 1 also revealed the presence of an acetate $\left(\delta_{\mathrm{C}} 170.2 \mathrm{~s}, 85.6 \mathrm{~s}, 22.8 \mathrm{q}, 1.98 \mathrm{~s}\right.$ [C-21, 22 and 15, respectively]) and an ether $\left(\delta_{\mathrm{C}} 63.4 \mathrm{~d}\right.$ and $61.5 \mathrm{~s}, \delta_{\mathrm{H}} 2.84$ [dd, 9.4, 3.4 Hz], [C-3 and C-4, respectively]). From the ${ }^{1} \mathrm{H}-{ }^{1} \mathrm{H}$ COSY spectrum of 1, three continuous chains of coupling were discerned; from $\mathrm{H}_{2}-13$ to $\mathrm{H}-3$ via $\mathrm{H}_{2}-14, \mathrm{H}-1$ and $\mathrm{H}_{2}-2$, respectively; from $\mathrm{H}_{2}-5$ to $\mathrm{H}_{3}-19$, via $\mathrm{H}_{2}-6$ and $\mathrm{H}-7$; and from $\mathrm{H}_{2}-9$ to $\mathrm{H}_{3}-20$, via $\mathrm{H}_{2}-10$, and $\mathrm{H}-11$, respectively. From long-range ${ }^{1} \mathrm{H}-{ }^{13} \mathrm{C}$ couplings observed between $\mathrm{H}_{3}-18$ and C-3, C-4 and C-5; between $\mathrm{H}_{3}-19$ and C-7, C-8 and C-9; and between $\mathrm{H}_{3}-20$ and C-11, C-12 and C-13, and from 1,1-ADEQUATE cross-peaks [23] (See Table 1), it was possible to link together the three proton spin systems into a continuous carbon chain to form the first ring within 1. The chemical shifts associated with C-3, C-4 and H-3 indicated the ether functionality was in fact an epoxide, and hence formed the second ring within 1, fulfilling the requirement for five double bond equivalents of unsaturation. The protons associated with two of the three unassigned methyl groups demonstrated long-range ${ }^{1} \mathrm{H}_{-}{ }^{13} \mathrm{C}$ couplings between each others carbon and, $\mathrm{C}-1$ and $\mathrm{C}-15$, giving rise to a gem-dimethyl constellation attached to $\mathrm{C}$-1, leaving the acetate function to reside at $\mathrm{C}-15$, leading to the planar structure of $\mathbf{1}$. The geometry of the two $\mathrm{C}=\mathrm{C}$ double bonds within $\mathbf{1}$ were both deduced to be $E$ based on the ${ }^{13} \mathrm{C}$ NMR chemical shifts of $\mathrm{C}-19$ and $\mathrm{C}-20\left(\delta_{\mathrm{C}} 16.7\right.$ and 15.3, respectively). Based on the observation that the ${ }^{13} \mathrm{C}$ NMR signals for $\mathrm{C}-2$ and $\mathrm{C}-18\left(\delta_{\mathrm{C}} 30.8\right.$ and 16.6, respectively) occurred significantly upfield of that for C-5 $\left(\delta_{\mathrm{C}} 39.3\right)$, resulting from steric compression 
due to their cis orientation, the relative stereochemistry of the epoxide is as shown in $\mathbf{1}$ [24]. This deduction was further supported by comparison of the ${ }^{13} \mathrm{C}$ NMR chemical shift data for C-3, C-4 and C-18 in 1 with those for $\mathbf{6}$, as well as the ${ }^{1} \mathrm{H}$ NMR data associated with $\mathrm{H}-3$ in both compounds. Selective 1D NOESY excitation of the epoxide proton H-3 $(\delta 2.84)$ gave rise to signals corresponding to $\mathrm{H}-1$ ( $\delta$ 2.22), H-2 $(\delta$ 1.56), H-5 ( $\delta 1.13), \mathrm{H}-7$ ( $\delta$ 5.23) and H-11 ( $\delta 5.13)$; this information, and comparison of both ${ }^{1} \mathrm{H}$ and ${ }^{13} \mathrm{C}$ NMR data with those for 6 confirmed the relative configuration at $\mathrm{C}-1$, 3 and 4 to be deduced as shown in $\mathbf{1}$. Unfortunately, the absolute stereochemistry of $\mathbf{1}$ could not be determined as the compound was unstable and degraded before an optical rotation could be obtained. Literature searches for this molecule revealed it to be a new compound and the acetylated derivative of 3,4-epoxy-nephthenol, 6 [28].

HRESIMS of 2, also isolated from Nephthea sp. specimen A, resulted in an $[\mathrm{M}+\mathrm{Na}]^{+}$ion corresponding to a molecular formula of $\mathrm{C}_{20} \mathrm{H}_{34} \mathrm{O}_{2}$ and hence four degrees of double bond unsaturation. The ${ }^{1} \mathrm{H}$ and ${ }^{13} \mathrm{C}$ NMR data of 2 revealed the presence of two $\mathrm{C}=\mathrm{C}$ double bonds $\left(\delta_{\mathrm{C}} 132.6 \mathrm{~s}, 132.1 \mathrm{~s}, 128.0 \mathrm{~d}\right.$ and $\left.127.7 \mathrm{~d}\right)$ as the only multiple bonds within the molecule indicating a bicyclic structure. Carbon chemical shifts indicated the presence of three oxygenated carbons $\left(\delta_{\mathrm{C}} 76.8 \mathrm{~s}, 75.1 \mathrm{~s}\right.$ and $\left.70.3 \mathrm{~d}\right)$, two of which formed an ether linkage accounting for one of the rings within 2, and the third an alcohol $\left(\delta_{\mathrm{H}} 4.20\right.$ [dd, 11.7, $5.6 \mathrm{~Hz}$, axial proton]). Database and literature searches using this information and comparison of spectroscopic data with literature values confirmed 2 to be the known compound decaryiol [28]. Selective 1D NOESY experiments enabled the relative configuration of 2 to be determined as shown; NOESY correlations were observed from $\mathrm{H}-3$ to $\mathrm{H}-1$, H-2, H-5, H-6, H-7 and H-11; from H-7 to H-3, H-5, H-6 $\left(\delta_{\mathrm{H}} 2.62\right.$ br and $\left.1.88 \mathrm{~s}\right)$ and H-9 $\left(\delta_{\mathrm{H}} 2.20\right.$ br and $2.17 \mathrm{~s}$ ); from $\mathrm{H}-11$ to $\mathrm{H}-1, \mathrm{H}-2, \mathrm{H}-3, \mathrm{H}-9, \mathrm{H}-10$ and $\mathrm{H}-13$; and from $\mathrm{H}-18$ to $\mathrm{H}-2$.

Accurate mass measurement of 3 showed it to have the molecular formula $\mathrm{C}_{20} \mathrm{H}_{32} \mathrm{O}$ and to contain five double bond equivalents of unsaturation. From the ${ }^{1} \mathrm{H}$ and ${ }^{13} \mathrm{C}$ NMR data of 3 it was evident that the molecule contained four $\mathrm{C}=\mathrm{C}$ double bonds $\left(\delta_{\mathrm{C}} 134.6 \mathrm{~s}, 133.4 \mathrm{~d}, 132.1 \mathrm{~s}, 131.5 \mathrm{~s}, 127.9 \mathrm{~d}, 127.3 \mathrm{~d}\right.$, $126.3 \mathrm{~d}$ and $126.2 \mathrm{~d}$ ), revealing it to be monocyclic. It was also evident from this data that $\mathbf{3}$ had one carbon attached to an oxygen, therefore an hydroxyl, functionality $\left(\delta_{\mathrm{C}} 72.3 \mathrm{~s}\right)$. As for $\mathbf{1}$, three chains of ${ }^{1} \mathrm{H}-{ }^{1} \mathrm{H}$ coupling were discerned from the COSY spectrum of 3; from $\mathrm{H}_{2}-13$ to $\mathrm{H}-3$ via $\mathrm{H}_{2}-14, \mathrm{H}-1$ and $\mathrm{H}_{2}-2$, respectively; from $\mathrm{H}_{3}-18$ to $\mathrm{H}_{3}-19$, via $\mathrm{H}-5, \mathrm{H}_{2}-6$ and $\mathrm{H}-7$; and from $\mathrm{H}_{2}-9$ to $\mathrm{H}_{3}-20$, via $\mathrm{H}_{2}-10$, and $\mathrm{H}-11$, respectively. From long-range ${ }^{1} \mathrm{H}^{13} \mathrm{C}$ couplings observed between $\mathrm{H}_{3}-18\left(\delta_{\mathrm{C}} 19.9, \Delta^{4} \mathrm{Z}\right.$ configuration) and C-4 and C-5; between $\mathrm{H}_{3}-19\left(\delta_{\mathrm{C}} 14.5, \Delta^{7} E\right.$ configuration) and C-7, C-8 and C-9; and between $\mathrm{H}_{3}-20\left(\delta_{\mathrm{C}} 14.3, \Delta^{11} E\right.$ configuration) and C-11, C-12 and C-13, and 1,1-ADEQUATE [23] cross-peaks (Figure 1), it was possible to link together the three proton spin systems into a continuous carbon chain to form the one ring within 3. HMBC and COSY correlations also confirmed two of the $\mathrm{C}=\mathrm{C}$ double bonds $\left(\Delta^{2}\right.$ and $\left.\Delta^{4}\right)$ were conjugated; $\mathrm{H}-2$ to $\mathrm{C}-4, \mathrm{H}-3$ to $\mathrm{C}-4$ and C-5, and $\mathrm{H}-5$ to $\mathrm{C}-3$, and that $\Delta^{2}$ had $E$ configuration $\left(\mathrm{H}-2: \delta_{\mathrm{H}} 5.20[\mathrm{dd}, 15.3,10.0 \mathrm{~Hz}] ; \mathrm{H}-3: \delta_{\mathrm{H}} 6.20[\mathrm{~d}, 15.3 \mathrm{~Hz}]\right)$. Comparison of these data with literature values for cembrenene (7) previously isolated from Sinularia mayi [26], (Table 2) indicated the structures to be similar. The protons associated with the two remaining methyl groups $\mathrm{CH}_{3}-16$ and $\mathrm{CH}_{3}-17$ demonstrated long-range ${ }^{1} \mathrm{H}-{ }^{13} \mathrm{C}$ couplings to each others protons and carbon and to $\mathrm{C}-1$ and $\mathrm{C}-15$ giving rise to a gem-dimethyl constellation attached to $\mathrm{C}-1$ with the hydroxyl moiety residing at $\mathrm{C}-15$, and the planar structure as shown in 3, 15-hydroxy-cembrenene. Literature searches for this molecule yielded a report detailing the synthetic dehydration of 2-hydroxy- 
nepthenol to give 3 [27]. The current report, however, is the first time $\mathbf{3}$ has been isolated from a natural source.

A second Nephthea sp., specimen B, was investigated for its anticancer activity with one of the active fractions yielding 4 , having the same molecular formula as $2, \mathrm{C}_{20} \mathrm{H}_{34} \mathrm{O}_{2}$. Comparison of the ${ }^{1} \mathrm{H}$ and ${ }^{13} \mathrm{C}$ NMR data of 4 with those of 2 showed it to contain only two oxygenated carbons $\left(\delta_{\mathrm{C}} 71.1 \mathrm{~d}\right.$ and $74.6 \mathrm{~s})$ as compared to the three in 2 , and three $\mathrm{C}=\mathrm{C}$ double bonds $\left(\delta_{\mathrm{C}} 139.5 \mathrm{~s}, 135.4 \mathrm{~s}, 133.3 \mathrm{~s}\right.$, $127.9 \mathrm{~d}, 124.9 \mathrm{~d}$ and $123.9 \mathrm{~d}$ ) rather than two as found in 2 , confirming it to be a monocyclic diol. Its 1D and 2D NMR data confirmed it to be 2-hydroxy-nephthenol [27]. After leaving 4 to stand for one week in $\mathrm{CDCl}_{3}$, it was found to have quantitatively rearranged to 3 . Given this result, it is unclear whether 3, previously reported synthetically [27] and reported here from Nephthea sp. specimen A, was in fact a natural product, or a by-product of the isolation process [27]. However, close inspection of fractions from specimen A shortly after they were prepared did not reveal the presence of any $\mathbf{4}$, leading us to believe that $\mathbf{3}$ is in actual fact naturally occurring.

Scheme 1. Structures of compounds 1-8 referred to throughout the publication.

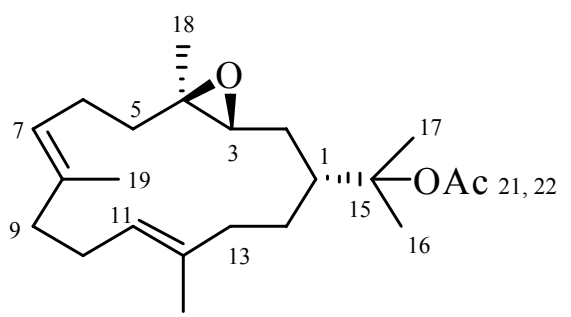

20

1

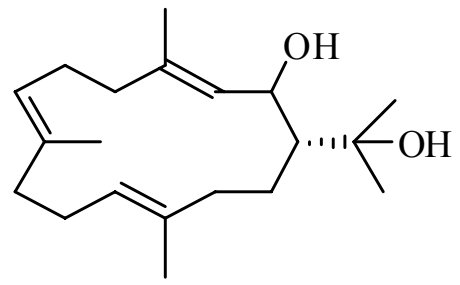

4

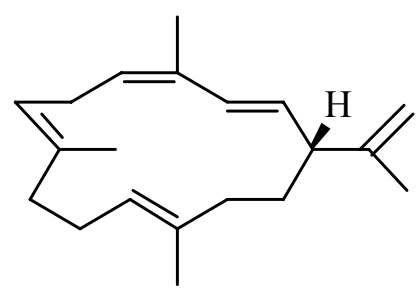

7

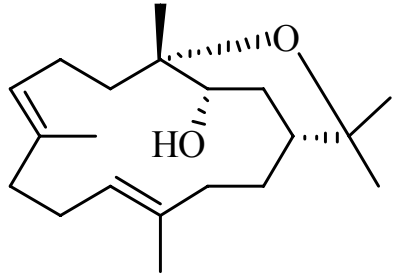

2

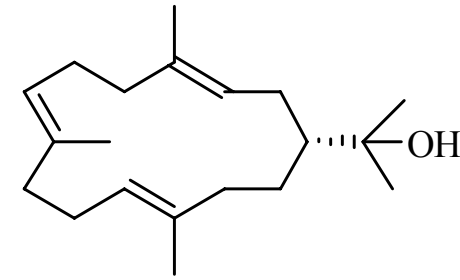

5

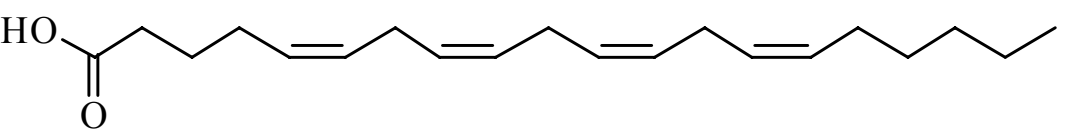

8

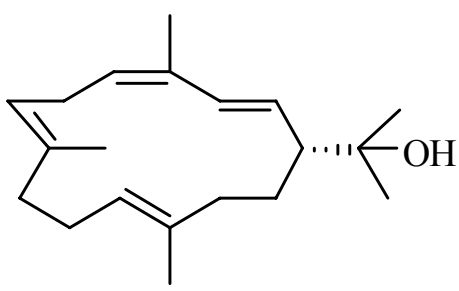

3

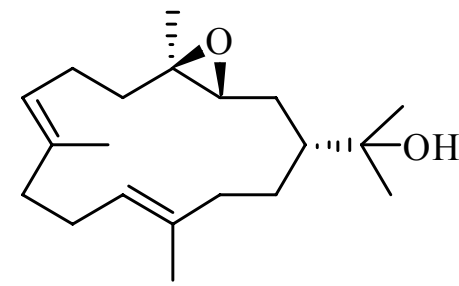

6

A second active compound, 5 , was isolated from specimen B. The mass spectrum of 5 showed an $[\mathrm{M}+\mathrm{Na}]^{+}$ion in its HRESIMS consistent with the molecular formula $\mathrm{C}_{20} \mathrm{H}_{34} \mathrm{O}$ and four degrees of $\mathrm{C}=\mathrm{C}$ unsaturation. The ${ }^{1} \mathrm{H}$ and ${ }^{13} \mathrm{C}$ NMR data of 5 showed it to contain three $\mathrm{C}=\mathrm{C}$ double bonds $\left(\delta_{\mathrm{C}} 134.1 \mathrm{~s}, 133.4 \mathrm{~s}, 133.0 \mathrm{~s}, 125.9 \mathrm{~d}, 125.8 \mathrm{~d}\right.$ and $\left.125.0 \mathrm{~d}\right)$ as well as one hydroxyl group $\left(\delta_{\mathrm{C}} 75.1 \mathrm{~s}\right)$, 
making it a monocyclic alcohol. Comparison of its spectroscopic data with literature values confirmed 5 to be nephthenol [28].

Table 1. ${ }^{1} \mathrm{H}$ and ${ }^{13} \mathrm{C}$ NMR data $\left(600 \mathrm{MHz}\right.$ basic frequency, $\mathrm{CDCl}_{3}$ ) for 3,4-epoxy-nephthenol acetate (1) and ${ }^{13} \mathrm{C}$ NMR data for 3,4-epoxy-nephthenol (6) (22.63 MHz, $\mathrm{CDCl}_{3}$ ).

\begin{tabular}{|c|c|c|c|c|c|c|}
\hline No. & $\delta_{\mathrm{C}}$, mult. $^{\mathrm{a}}(\mathbf{1})$ & $\delta_{\mathrm{H}}($ mult., $J$ in $\mathrm{Hz})(\mathbf{1})$ & $\operatorname{COSY}(\mathbf{1})$ & $\operatorname{gHMBC}(\mathbf{1})^{\mathrm{b}}$ & 1,1-Adequate (1) ${ }^{\mathrm{b}}$ & $\delta_{\mathrm{C}}$, mult. $(\mathbf{6})^{25}$ \\
\hline 1 & $39.5 \mathrm{~d}$ & $2.22(\mathrm{~m})$ & 2,14 & $2,3,14,15,16,17$ & $2,14,15$ & $44.1 \mathrm{~d}$ \\
\hline 2 & $30.8 \mathrm{t}$ & $1.56(\mathrm{~m})$ & 1,3 & $3,4,14,15$ & & $29.7 \mathrm{t}$ \\
\hline 3 & $63.4 \mathrm{~d}$ & $\begin{array}{l}2.84(\mathrm{dd}, 9.4,3.4) \\
\text { cf. } 2.82(\mathrm{dd}, 9.2,4.4)^{25}\end{array}$ & 2 & $1,2,4,5$ & 2 & $63.0 \mathrm{~d}$ \\
\hline 4 & $61.5 \mathrm{~s}$ & & & & & $61.9 \mathrm{~s}$ \\
\hline 5 & $39.3 \mathrm{t}$ & $\begin{array}{l}2.06(\mathrm{ddd}, 13.3,5.4,2.9) \\
1.14(\mathrm{dt}, 13.3,3.2)\end{array}$ & $\begin{array}{l}5 \mathrm{~b}, 6 \\
5 \mathrm{a}, 6\end{array}$ & $\begin{array}{l}4,7 \\
4,6,7,18\end{array}$ & 4,6 & $39.9 \mathrm{t}$ \\
\hline 6 & $23.8 \mathrm{t}$ & $\begin{array}{l}2.26(\mathrm{~m}) \\
1.97(\mathrm{~m}) \\
\end{array}$ & $\begin{array}{l}5,6 \mathrm{~b}, 7 \\
6 \mathrm{a}, 7 \\
\end{array}$ & $\begin{array}{l}4,5,7,8 \\
4,5,7,8,9 \\
\end{array}$ & $\begin{array}{l}7 \\
5 \\
\end{array}$ & $23.6 \mathrm{t}$ \\
\hline 7 & $123.6 \mathrm{~d}$ & 5.23 (brt, 7.6) & $6 a, 6 b, 19$ & $6,9,19$ & 6,7 & $125.9 \mathrm{~d} *$ \\
\hline 8 & $134.9 \mathrm{~s}$ & & & & & $133.8 \mathrm{~s} *$ \\
\hline 9 & $39.8 \mathrm{t}$ & $\begin{array}{l}2.03(\mathrm{~m}) \\
2.18(\mathrm{~m})\end{array}$ & & $7,8,10,11,19$ & $\begin{array}{l}10 \\
8,10\end{array}$ & $36.6 \mathrm{t} *$ \\
\hline 10 & $25.0 \mathrm{t}$ & $2.17(\mathrm{~m})$ & 11 & $8,9,11$ & 9,11 & $24.9 \mathrm{t}$ \\
\hline 11 & $126.2 \mathrm{~d}$ & 5.13 (brt, 7.5) & 10,20 & $10,13,20$ & $10,11,13$ & $123.9 \mathrm{~d} *$ \\
\hline 12 & $132.4 \mathrm{~s}$ & & & & & $134.9 \mathrm{~s} *$ \\
\hline 13 & $35.6 \mathrm{t}$ & $2.19(\mathrm{~m})$ & $14 \mathrm{a}, 14 \mathrm{~b}$ & 11,12 & 12,14 & $39.1 \mathrm{t} *$ \\
\hline 14 & $28.9 \mathrm{t}$ & $\begin{array}{l}1.89(\mathrm{~m}) \\
1.34(\mathrm{~m}) \\
\end{array}$ & $\begin{array}{l}1,13,14 \mathrm{~b} \\
1,13,14 \mathrm{a}\end{array}$ & $\begin{array}{l}1,2,12,13,15,17 \\
12,15,17\end{array}$ & 13 & $28.1 \mathrm{t}$ \\
\hline 15 & $85.6 \mathrm{~s}$ & & & & & $73.3 \mathrm{~s}$ \\
\hline 16 & $23.5 \mathrm{q}$ & $1.45(\mathrm{~s})$ & & $1,15,17$ & 15 & $26.6 \mathrm{q}$ \\
\hline 17 & $23.4 \mathrm{q}$ & $1.43(\mathrm{~s})$ & & $1,15,16$ & 15 & $28.6 \mathrm{q}$ \\
\hline 18 & $16.7 \mathrm{q}$ & $1.31(\mathrm{~s})$ & & $3,4,5$ & 4 & $16.9 \mathrm{q}$ \\
\hline 19 & $15.3 \mathrm{q}$ & 1.62 (brs) & 7 & $7,8,9$ & 8 & $16.0 \mathrm{q} *$ \\
\hline 20 & $15.8 \mathrm{q}$ & 1.58 (brs) & 11 & $11,12,13$ & 12 & $15.5 \mathrm{q} *$ \\
\hline 21 & $170.2 \mathrm{~s}$ & & & & & \\
\hline 22 & $22.8 \mathrm{q}$ & $1.98(\mathrm{~s})$ & & 21 & 21 & \\
\hline
\end{tabular}

* Based on the shifts found for $\mathbf{1}$, these carbon resonances probably need reassignment.

${ }^{\mathrm{a}}$ Correlations are from proton to carbon; ${ }^{\mathrm{b}}$ Multiplicities determined by DEPT.

Compound 8 was isolated as a yellow oil with the molecular formula of $\mathrm{C}_{20} \mathrm{H}_{32} \mathrm{O}_{2}$, as determined by HRESIMS measurement of its $[\mathrm{M}-\mathrm{H}]{ }^{-}$ion. Analysis of the ${ }^{1} \mathrm{H}$ and ${ }^{13} \mathrm{C}$ NMR spectral data of 8 in $\mathrm{CDCl}_{3}$ revealed signals consistent with the presence of a carboxyl group $\left(\delta_{\mathrm{C}} 177.9 \mathrm{~s}\right)$ and eight $\mathrm{sp}^{2}$ methine carbons $\left(\delta_{\mathrm{C}} 130.5 \mathrm{~d}, 129.0 \mathrm{~d}, 128.8 \mathrm{~d}, 128.6 \mathrm{~d}, 128.3 \mathrm{~d}, 128.1 \mathrm{~d}, 127.9 \mathrm{~d}\right.$ and $\left.127.5 \mathrm{~d}\right)$ accounting for all five of the $\mathrm{C}=\mathrm{C}$ double bond equivalents of unsaturation within the molecule and showing it to be acyclic. Signals from three methylene carbons adjacent to cis double bonds were observed at $\delta_{\mathrm{C}} 25.6,25.6$ and 25.6, as well as for seven other methylene carbons and one methyl group $\left(\delta_{\mathrm{C}} 14.0\right)$. Comparison of these values with literature values confirmed $\mathbf{8}$ as the fatty acid arachidonic $(20: 4 n-6)$ acid [29]. 
Compounds 1-5, and 8 were screened for their whole cell anticancer activity against three human tumor cell lines (SF-268 [CNS], MCF-7 [breast], H460 [lung]). All compounds demonstrated weak $\left(\mathrm{GI}_{50}>100 \mu \mathrm{M}\right)$ non-selective activity towards the three cell lines.

Table 2. ${ }^{1} \mathrm{H}$ and ${ }^{13} \mathrm{C}$ NMR data (125 $\mathrm{MHz}, \mathrm{CDCl}_{3}$ ) for 15-hydroxy-cembrenene (3); ${ }^{13} \mathrm{C} \mathrm{NMR}$ data $\left(125 \mathrm{MHz}, \mathrm{CDCl}_{3}\right.$ ) for decaryiol (2), 2-hydroxy-nephthenol (4) and nephthenol (5); (22.6 MHz, $\mathrm{CDCl}_{3}$ ) for 3,4-epoxy-nephthenol (6), cembrenene (7) and arachidonic acid (8).

\begin{tabular}{|c|c|c|c|c|c|c|c|}
\hline No. & 2 & 3 & 3 & 7 & 4 & 5 & 8 \\
\hline & $\delta_{\mathrm{C}}$, mult. $^{\text {a }}$ & $\delta_{\mathrm{C}}$, mult. ${ }^{\mathrm{a}}$ & $\delta_{\mathrm{H}},($ mult., $J \mathrm{~Hz}$ ) & $\delta_{\mathrm{C}}$, mult. & $\delta_{\mathrm{C}}$, mult. $^{\mathrm{a}}$ & $\delta_{\mathrm{C}}$, mult. $^{\mathrm{a}}$ & $\delta_{\mathrm{C}}$, mult. ${ }^{\mathrm{a}}$ \\
\hline 1 & $39.9 \mathrm{~d}$ & $53.5 \mathrm{~d}$ & $1.85(\mathrm{ddd}, 2.5,9.9,12.3)$ & $49.0 \mathrm{~s}$ & $53.8 \mathrm{~d}$ & $48.3 \mathrm{~d}$ & $177.0 \mathrm{~s}$ \\
\hline 2 & $28.8 \mathrm{t}$ & $127.9 \mathrm{~d}$ & $5.21(\mathrm{dd}, 9.9,15.5)$ & $130.5 \mathrm{~d}$ & $71.1 \mathrm{~d}$ & $28.4 \mathrm{t}$ & $33.0 \mathrm{t}$ \\
\hline 3 & $70.3 \mathrm{~d}$ & $133.4 \mathrm{~d}$ & $6.21(\mathrm{brd}, 15.5)$ & $132.3 \mathrm{~d}$ & $127.9 \mathrm{~d}$ & $126.0 \mathrm{~d}$ & $24.5 \mathrm{t}$ \\
\hline 4 & $76.8 \mathrm{q}$ & $134.6 \mathrm{~s}$ & & $135.1 \mathrm{~s}$ & $139.5 \mathrm{~s}$ & $134.1 \mathrm{~s}$ & $26.4 \mathrm{t}$ \\
\hline 5 & $37.9 \mathrm{t}$ & $127.3 \mathrm{~d}$ & $5.61(\mathrm{brdd}, 6.9,9.0)$ & $126.7 \mathrm{~d}$ & $39.4 \mathrm{t}$ & $38.5 \mathrm{t}$ & $129.0 \mathrm{~d}$ \\
\hline 6 & $23.6 \mathrm{t}$ & $26.2 \mathrm{t}$ & $\begin{array}{c}2.43 \text { (brddd, 3.7, 9.0, 15.3) } \\
3.06 \text { (brddd, 6.9, 10.9, 15.3) }\end{array}$ & $29.1 \mathrm{t}$ & $24.5 \mathrm{t}$ & $24.7 \mathrm{t}$ & $128.2 \mathrm{~d}$ \\
\hline 7 & $127.7 \mathrm{~d}$ & $126.3 \mathrm{~d}$ & 5.09 (brdd, $3.7,10.9)$ & $126.3 \mathrm{~d}$ & $124.9 \mathrm{~d}$ & $125.9 \mathrm{~d}$ & $25.6 \mathrm{t}$ \\
\hline 8 & $132.1 \mathrm{~s}$ & $131.5 \mathrm{~s}$ & & $130.5 \mathrm{~s}$ & $133.3 \mathrm{~s}$ & $133.2 \mathrm{~s}$ & $128.8 \mathrm{~d}$ \\
\hline 9 & $39.2 \mathrm{t}$ & $38.8 \mathrm{t}$ & $\begin{array}{l}2.04(\mathrm{~m}) \\
2.19(\mathrm{~m})\end{array}$ & $38.9 \mathrm{t}$ & $39.7 \mathrm{t}$ & $39.5 \mathrm{t}$ & $127.9 \mathrm{~d}$ \\
\hline 10 & $25.1 \mathrm{t}$ & $23.5 \mathrm{t}$ & $\begin{array}{l}2.28(\mathrm{~m}) \\
2.01(\mathrm{~m})\end{array}$ & $23.5 \mathrm{t}$ & $23.4 \mathrm{t}$ & $24.1 \mathrm{t}$ & $25.6 \mathrm{t}$ \\
\hline 11 & $128.0 \mathrm{~d}$ & $126.2 \mathrm{~d}$ & 4.85 (brdd, $4.2,7.4)$ & $126.3 \mathrm{~d}$ & $123.9 \mathrm{~d}$ & $125.0 \mathrm{~d}$ & $128.1 \mathrm{~d}$ \\
\hline 12 & $132.6 \mathrm{~s}$ & $132.1 \mathrm{~s}$ & & $131.4 \mathrm{~s}$ & $135.4 \mathrm{~s}$ & $133.1 \mathrm{~s}$ & $128.6 \mathrm{~d}$ \\
\hline 13 & $36.3 \mathrm{t}$ & $36.3 \mathrm{t}$ & $\begin{array}{l}1.95(\mathrm{dt}, 6.7,3.9) \\
2.08(\mathrm{~m})\end{array}$ & $36.4 \mathrm{t}$ & $39.8 \mathrm{t}$ & $37.5 \mathrm{t}$ & $25.6 \mathrm{t}$ \\
\hline 14 & $25.2 \mathrm{t}$ & $24.9 \mathrm{t}$ & $\begin{array}{l}1.80(\mathrm{~m}) \\
2.07(\mathrm{~m})\end{array}$ & $26.3 \mathrm{t}$ & $28.9 \mathrm{t}$ & $28.2 \mathrm{t}$ & $127.5 \mathrm{~d}$ \\
\hline 15 & $75.1 \mathrm{~s}$ & $72.3 \mathrm{~s}$ & & $149.7 \mathrm{~s}$ & $74.6 \mathrm{~s}$ & $73.4 \mathrm{~s}$ & $130.5 \mathrm{~d}$ \\
\hline 16 & $29.5 \mathrm{q}$ & $27.3 \mathrm{q}$ & $1.19(\mathrm{~s})$ & $108.8 \mathrm{t}$ & $29.9 \mathrm{q}$ & $27.6 \mathrm{q}$ & $27.3 \mathrm{t}$ \\
\hline 17 & $22.2 \mathrm{q}$ & $26.9 \mathrm{q}$ & $1.13(\mathrm{~s})$ & $21.5 \mathrm{q}$ & $24.6 \mathrm{q}$ & $27.6 \mathrm{q}$ & $29.3 \mathrm{t}$ \\
\hline 18 & $24.2 \mathrm{q}$ & $19.9 \mathrm{q}$ & $1.80(\mathrm{t}, 1.5)$ & $19.8 \mathrm{q}$ & $15.4 \mathrm{q}$ & $15.6 \mathrm{q}$ & $31.5 \mathrm{t}$ \\
\hline 19 & $14.8 \mathrm{q}$ & $14.5 \mathrm{q}$ & 1.59 (brs) & $14.4 \mathrm{q}$ & $15.2 \mathrm{q}$ & $15.3 \mathrm{q}$ & $22.6 \mathrm{t}$ \\
\hline 20 & $15.0 \mathrm{q}$ & $14.3 \mathrm{q}$ & 1.53 (brs) & $14.4 \mathrm{q}$ & $15.8 \mathrm{q}$ & $15.6 \mathrm{q}$ & $14.0 \mathrm{q}$ \\
\hline
\end{tabular}

${ }^{\text {a }}$ Multiplicities determined by DEPT.

\section{Experimental Section}

\subsection{General experimental}

C18 flash vacuum chromatography was performed using Phenomenex C18 $(50 \mu \mathrm{m})$. HPLC was performed employing a Phenomenex Luna C18 column $(250 \times 21 \mathrm{~mm})$ attached to a Shimadzu HPLC system consisting of a Shimadzu SCL-10Avp system controller equipped with a Shimadzu LC-10AT pump, Shimadzu SPD-M10Avp photodiode array detector, Shimadzu FRC-10A fraction collector and 
Shimadzu SIL-10A auto sampler using Shimadzu Class-VP software. IR spectra were measured on a Nicolet Nexus FTIR. Optical rotations were collected on a Jasco 715 CD polarimeter. All NMR spectra were recorded on either a Bruker Avance $600 \mathrm{MHz}$ NMR spectrometer complete with cryoprobe, or a Bruker Avance $300 \mathrm{MHz}$ NMR spectrometer, with spectra referenced to residual ${ }^{1} \mathrm{H}$ and ${ }^{13} \mathrm{C}$ resonances in the deuterated solvents. Accurate mass spectrometric data were measured using a Bruker BioApex 47 FT mass spectrometer. All other details as previously published [30].

\subsection{Animal material}

Nephthea sp. specimen A was collected from Seribu Islands, DKI Jakarta, Indonesia, at a depth of $10 \mathrm{~m}$, at 10:21 am, on the 22 July 2005; Nephthea sp. specimen B was collected from Seribu Islands, DKI Jakarta, Indonesia, at a depth of $15 \mathrm{~m}$, at 1:10 pm, on the 22 June, 2005. Soft coral taxonomy was undertaken by K. Fabricius, AIMS. A voucher sample for each specimen has been lodged with the Indonesia Research Center for Marine and Fisheries Product Processing and Biotechnology, Jakarta, Indonesia.

Figure 1. 1,1-ADEQUATE spectrum of 3 (600 $\mathrm{MHz}$ basic frequency, $\left.\mathrm{CDCl}_{3}\right)$.

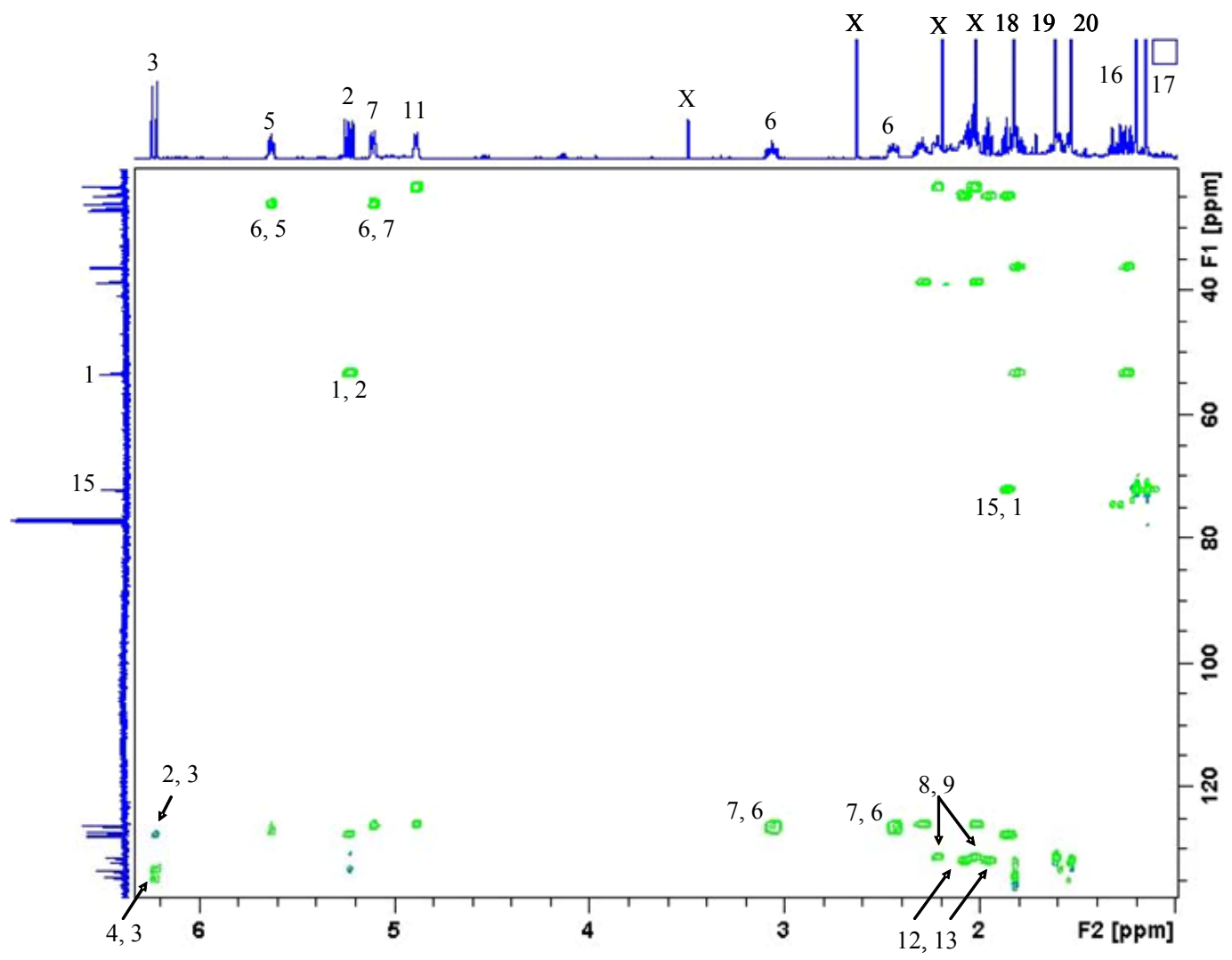

X: Residual solvents.

Numbered correlations - e.g., 2, 3-are from carbon (e.g., 2) to proton (e.g., 3).

\subsection{Bioassay}

Natural product samples were assayed against three cell lines; SF-268, MCF-7 and H460 cells, as described in a previous study [31]. In brief, natural product samples, solubilized in DMSO and serially diluted in RPMI 1640 medium, were added to SF-268, MCF-7 and H460 cells so that the final doses 
ranged from $1000 \mu \mathrm{g} / \mathrm{mL}$ to $1 \mu \mathrm{g} / \mathrm{mL}$. Total cellular protein was measured using the sulforhodamine B (SRB) assay as an indicator of cell number. Inhibition of growth by $50 \%\left(\mathrm{GI}_{50}\right)$ was determined by comparing the sample treated values to those of vehicle only control and time 0 readings.

\subsection{Extraction and isolation}

Extract A: The organic solubles $(0.84 \mathrm{~g})$, obtained by employing repeated extraction of $100.00 \mathrm{~g}$ wet weight of Nephthea sp. specimen A with $\mathrm{MeOH}$, were filtered through a plug of reversed phase $\mathrm{C} 18$ silica using $\mathrm{MeOH}$ as eluent. The $\mathrm{MeOH}$ was removed under reduced pressure and the resultant dry extract subjected to preparative RP-HPLC $\left(9 \mathrm{~mL} / \mathrm{min}\right.$, gradient elution from $15 \% \mathrm{MeCN}: \mathrm{H}_{2} \mathrm{O}$ to 100\% MeCN; column $250 \times 20 \mathrm{~mm}$ RP Luna C18 (2), Phenomenex, over 70 mins) to yield 63 fractions. Three of the 63 fractions, 27, 30 and 32, were found to be active in the applied bioassay systems. ${ }^{1} \mathrm{H}$ NMR analysis of these fractions showed them to be a 1:1 mixture of 3 and $\mathbf{4}(10.0 \mathrm{mg}, 1.19 \%$ organic extract), 8 (10.0 mg, 1.19\% organic extract), and 5 (10.0 mg, 1.19\% organic extract), respectively.

Extract B: The organic solubles $(3.31 \mathrm{~g})$, obtained by employing repeated extraction of $300.00 \mathrm{~g}$ wet weight of Nephthea sp. specimen B with $\mathrm{MeOH}$, were filtered through a plug of reversed phase $\mathrm{C} 18$ silica using $\mathrm{MeOH}$ and DCM as eluents. The $\mathrm{MeOH}$ and DCM were removed under reduced pressure and the resultant dry extracts $(1.49 \mathrm{~g}$ and $0.10 \mathrm{~g}$, respectively) subjected to preparative RP-HPLC. The $\mathrm{MeOH}$ extract $\left(9 \mathrm{~mL} / \mathrm{min}\right.$, gradient elution from $15 \% \mathrm{MeCN}: \mathrm{H}_{2} \mathrm{O}$ to $100 \% \mathrm{MeCN}$; column $250 \times 20 \mathrm{~mm}$ RP Luna C18 (2), Phenomenex, over $70 \mathrm{mins}$ ) yielded 57 fractions of which only one, fraction 35 , was found to be active in the applied bioassay systems. ${ }^{1} \mathrm{H}$ NMR analysis of this fraction showed it to be $2(57.9 \mathrm{mg}, 1.75 \%$ organic extract). The DCM extract $(9 \mathrm{~mL} / \mathrm{min}$, gradient elution from 15\% MeCN: $\mathrm{H}_{2} \mathrm{O}$ to $100 \% \mathrm{MeCN}$; column $250 \times 20 \mathrm{~mm}$ RP Luna C18 (2), Phenomenex, over 70 mins) yielded 55 fractions of which two, fractions 16 and 18, were found to be active in the applied bioassay systems. ${ }^{1} \mathrm{H}$ NMR analysis of these fractions showed them to be $3(2.3 \mathrm{mg}, 0.07 \%$ organic extract), and $\mathbf{1}(0.8 \mathrm{mg}, 0.02 \%$ organic extract), respectively.

Compound 1 (3,4-Epoxy-nephthenol acetate). A yellow oil; $[\alpha]_{\mathrm{D}}$ Sample decomposed prior to measurement; ${ }^{1} \mathrm{H}\left(600 \mathrm{MHz}, \mathrm{CDCl}_{3}\right)$, and ${ }^{13} \mathrm{C}\left(150 \mathrm{MHz}, \mathrm{CDCl}_{3}\right)$ NMR data see Table 1; HRESIMS $\mathrm{m} / \mathrm{z}$ found 371.2563 for $[\mathrm{M}+\mathrm{Na}]^{+}$(calcd for $\mathrm{C}_{22} \mathrm{H}_{36} \mathrm{O}_{3} \mathrm{Na} 371.2557$ ).

Compound 2 (Decaryiol). A yellow oil $[\alpha]_{\mathrm{D}}{ }^{20}+27.2^{\circ}$ (c 0.01$)$, cf $+69.0^{\circ}[25] ;{ }^{13} \mathrm{C}(150 \mathrm{MHz}$, $\mathrm{CDCl}_{3}$ ) NMR data see Table 2; HRESIMS $\mathrm{m} / \mathrm{z}$ found 329.2458 for $[\mathrm{M}-\mathrm{H}]^{+}$(calcd for $\mathrm{C}_{20} \mathrm{H}_{34} \mathrm{O}_{2} \mathrm{Na}$ 329.2451); and all remaining data as previously published [25].

Compound 3 (15-Hydroxy-cembrenene). A yellow oil; $[\alpha]_{\mathrm{D}}$ Sample decomposed prior to measurement; ${ }^{1} \mathrm{H}\left(600 \mathrm{MHz}, \mathrm{CDCl}_{3}\right)$ and ${ }^{13} \mathrm{C}\left(150 \mathrm{MHz}, \mathrm{CDCl}_{3}\right)$ NMR data see Table 2; HRESIMS $\mathrm{m} / \mathrm{z}$ found 311.2330 for $[\mathrm{M}-\mathrm{H}]^{+}$(calcd for $\mathrm{C}_{20} \mathrm{H}_{32} \mathrm{ONa} 311.2345$ ); and all remaining data as previously published [27].

Compound 4 (2-Hydroxy-nephthenol). A clear oil ${ }^{13} \mathrm{C}\left(150 \mathrm{MHz}, \mathrm{CDCl}_{3}\right) \mathrm{NMR}$ data see Table 2; HRESIMS $\mathrm{m} / \mathrm{z}$ found 329.2452 for $[\mathrm{M}+\mathrm{Na}]^{+}$(calcd for $\mathrm{C}_{20} \mathrm{H}_{34} \mathrm{O}_{2} \mathrm{Na} 329.2451$ ); and all remaining data as previously published [27]. 
Compound 5 (Nephthenol). A clear oil; ${ }^{13} \mathrm{C}\left(150 \mathrm{MHz}, \mathrm{CDCl}_{3}\right)$ NMR data see Table 2; HRESIMS $\mathrm{m} / \mathrm{z}$ found 313.2517 for $[\mathrm{M}-\mathrm{H}]^{+}$(calcd for $\mathrm{C}_{20} \mathrm{H}_{34} \mathrm{ONa} 313.2502$ ); and all remaining data as previously published [28].

Compound 8 (Arachidonic acid). A yellow oil; ${ }^{13} \mathrm{C}\left(150 \mathrm{MHz}, \mathrm{CDCl}_{3}\right)$ NMR data see Table 2; HRESIMS $m / z$ found 303.2325 for $\left[\mathrm{M}-\mathrm{H}_{2} \mathrm{O}+\mathrm{Na}\right]^{+}$(calcd for $\mathrm{C}_{20} \mathrm{H}_{31} \mathrm{O}_{2}$ 303.2330); and all remaining data as previously published [29].

\section{Acknowledgements}

This study was supported by AusAID through PSLP-Indonesia project ROU 37118. Many thanks go to our Marine Biotechnology team at the Indonesian Research Center for Marine and Fisheries Product Processing and Biotechnology for their collaborations in sample collection. Our thanks also go to A. Sabdono and O. Karnaradjasa, Diponegoro University, Indonesia, for provision of samples from Bali and J. Neilson, AIMS, for technical assistance with HPLC separations.

\section{References}

1. Hay, M.E.; Duffy, J.E.; Pfister, A.P.; Fenical, W. Chemical defense against different marine herbivores: are amphipods insect equivalents? Ecology 1986, 68, 1567-1580.

2. De Nys, R.; Steinberg, P.D.; Willemsen, P.; Dworjanyn, S.A.; Gabelish, C.L.; King, R.J. Broad spectrum effects of secondary metabolites from the red alga Delisea pulchra in antifouling assays. Biofouling 1995, 8, 259-271.

3. De Nys, R.; Steinberg, P.D. Role of secondary metabolites from algae and seagrasses in biofouling control. In Recent Advances in Marine Biotechnology: Biofilms, Bioadhesion, Corrosion and Biofouling; Fingerman, M., Nagabhushanam, R., Thompson, M.-F., Eds.; Science Publishers: Enfield, NH, USA, 1999; Volume 3, pp. 223-244.

4. Pennings, S.C.; Pablo, S.R.; Paul, V.J. Chemical defenses of the tropical, benthic marine cyanobacterium Hormothamnion enteromorphoides: Diverse consumers and synergisms. Limnol. Oceanogr. 1997, 42, 911-917.

5. Wright, A.D.; Wang, H.; Gurrath, M.; König, G.M.; Kocak, G.; Neumann, G.; Loria, P.; Foley, M.; Tilley, L. Inhibition of heme (FP) detoxification processes underlies the antimalarial activity of terpene isonitrile compounds from marine sponges. J. Med. Chem. 2001, 44, 873-885.

6. König, G.M.; Wright, A.D.; Linden, A. Antiplasmodial and Cytotoxic Metabolites from the Maltese Sponge Agelas oroides. Planta Med. 1998, 64, 443-447.

7. Rinehart, K.L.; Morales, J.J.; Reid, J.; Reymundo, I.; Floriano, P.; Gravalos, L.G. ETM-775 metabolite of ecteinascidin 743. 13 November 2001, US Patent 6,316,214 B1.

8. Coll, J.C.; La Barre, S.; Sammarco, P.W.; Williams, W.T.; Bakus, G.J. Chemical defence in soft corals of the Great Barrier Reef: A study of comparative toxicities. Mar. Ecol. Prog. Ser. 1988, 8, 271-278.

9. Coll, J.C.; Bowden, B.F.; Tapiolas, D.M.; Dunlap, W.C. In situ isolation of allelochemicals from soft corals (Coelenterata: Octocorallia): a totally submersible sampling apparatus. J. Exp. Mar. Biol. Ecol. 1982, 60, 292-299. 
10. Schmitz, F.J.; Hollenbeak, K.H.; Prasad, R.S. Marine natural products: Cytotoxic spermidine derivatives from the soft coral Sinularia brongersmai. Tetrahedron Lett. 1979, 20, 3387-3390.

11. Weinheimer, A.J.; Matson, J.A.; Hossain, M.B.; van der Helm, D. Marine anticancer agents: Sinularin and dihydrosinularin, new cembranolides from the soft coral, Sinularia flexibilis. Tetrahedron Lett. 1977, 34, 2923-2926.

12. Kobayashi, J.; Ohizumi, Y.; Nakamura, H.; Yamakado, T.; Matsuzaki, T.; Hirata, Y. Ca-antagonistic substance from soft coral of the genus Sarcophyton. Experientia 1983, 39, 67-69.

13. Handayani, D.; Edrada, R.A.; Proksch, P.; Wray, V.; Witte, L.; van Ofwegen, L.; Kunzmann, A. New Oxygenated Sesquiterpenes from the Indonesian Soft Coral Nephthea chabrolii. J. Nat. Prod. 1997, 60, 716-718.

14. Morris, L.A.; Christie, E.M.; Jaspars, M.; van Ofwegen, L. A bioactive secosterol with unusual Aand B-ring oxygenation pattern isolated from an Indonesian soft coral Lobophytum sp. J. Nat. Prod. 1998, 61, 538-541.

15. Anta, C.; Gonzalez, N.; Santafe, G.; Rodriguez, J.; Jimenez, C. New Xenia diterpenoids from the Indonesian soft coral Xenia sp. J. Nat. Prod. 2002, 65, 766-768.

16. Anta, C.; Gonzalez, N.; Rodriguez, J.; Jimenez, C. A new secosterol from the Indonesian octocoral Pachyclavularia violacea. J. Nat. Prod. 2002, 65, 1357-1359.

17. Fattorusso, E.; Romano, A.; Taglialatela-Scafati, O.; Irace, C.; Maffettone, C.; Bavestrello, G.; Cerrano, C. Oxygenated cembranoids of the decaryiol type from the Indonesian soft coral Lobophytum sp. Tetrahedron 2009, 65, 2898-2904.

18. Wang, W.; Lee, J.-S.; Ukai, K.; Mangindaan, R.E.P.; Wewengkang, D.S.; Rotinsulu, H.; Kobayashi, H.; Tsukamoto, S.; Namikosh, M. (25S)-Cholesten-26-oic acid derivatives from an Indonesian soft coral Minabea sp. Steroids 2009, 74, 758-760.

19. Januar, H.I.; Chasanah, E.; Tapiolas, D.M.; Motti, C.A.; Wright, A.D. Cembranes from two different Nephthea sp., collected from Indonesian waters. In the 50th Annual Meeting of the American Society of Pharmacognosy, Honolulu, HI, USA, 27 June 2009-1 July 2009; Conference Abstracts, p. 111.

20. Januar, H.I.; Chasanah, E.; Tapiolas, D.M.; Motti, C.A.; Wright, A.D. Cytotoxic cembranes from Indonesian specimens of the soft coral Nephthea sp. In the 51st Annual Meeting of the American Society of Pharmacognosy, St. Petersburg Beach, Florida, USA, 10-14 July 2010; Conference Abstracts, p. 50.

21. Chasanah, E.; Januar, H.I.; Bourne, D.; Liptrot, C.; Wright, A.D. Screening of Anti-cancer Activity of Fungi Derived from Indonesia Marine Sponges. In World Ocean Conference Side Event, International Symposium on Ocean Science, Technology and Policy, Manado, North Sulawesi, Indonesia, 12-14 May 2009; Conference Abstracts, Chapter IV-B, p. 10.

22. Januar, H.I.; Chasanah, E.; Liptrot, C.; Doyle, J.; Nielson, J.; Tapiolas, D.; Motti, C.; Wright, A.D. Dereplication of Active Extracts Obtained from Indonesian Marine Organisms. In the 48th Annual Meeting of the American Society of Pharmacognosy, Portland, ME, USA, 14-18 July 2007; Congress Abstracts, P-012M.

23. Köck, M.; Reif, B.; Gerlach, M.; Reggelin, M. Application of the 1,n-ADEQUATE experiment in the assignment of highly substituted aromatic compounds. Molecules 1996, 1, 41-45. 
24. Greenland, G.J.; Bowden, B.F. Cembranoid Diterpenes Related to Sarcophytol A from the Soft Coral Sarcophyton trocheliophorum (Alcyonacea). Aust. J. Chem. 1994, 47, 2013-2021.

25. Carmely, S.; Groweiss, A.; Kashman, Y. Decaryiol, a New Cembrane from the Marine Soft Coral Sarcophyton decaryi. J. Org. Chem. 1981, 46, 4279-4284.

26. Uchio, Y.; Nabeya, H.; Nakayama, M.; Hayashi, S.; Hase, T. Cembrenene and mayol, two new cembranoid diterpenes from the soft coral Sinularia mayi. Tetrahedron Lett. 1981, 22, 1689-1690.

27. Tursch, B.; Braekman, J.C.; Daloze, D. Chemical studies of marine invertebrates. XIII. 2-Hydroxynephthenol, a novel cembrane diterpene from the soft coral Litophyton viridis (Coelenterata, Octocorallia, Alcyonacea). Bull. Soc. Chim. Belg. 1975, 84, 767-774.

28. Schmitz, F.J.; Vanderah, D.J.; Ciereszko, L.S. Marine natural products. nephthenol and epoxynephthenol acetate, cembrene derivatives from a soft coral. J. Chem. Soc. Chem. Commun. 1974, 10, 407-408.

29. Jyothirmayi, N.; Ramadoss, C.S; Divakar, S. Nuclear magnetic resonance studies of cylodextrin complexes of linoleic acid and arachidonic acid. J. Agric. Food Chem. 1991, 39, 2123-2127.

30. Tapiolas, D.M.; Bowden, B.; Motti, C.A.; Willis, R.H.; Abou-Mansour, E.; Bourne, D.; Doyle, J.R.; Llewellyn, L.; Wright, A.D. Eusynstyelamides A, B and C from the Ascidian Eusynstyela latericus and Revision of the Structure of Eusynstyelamide. J. Nat. Prod. 2009, 72, 1115-1120.

31. Wright, A.D.; Nielson, J.L.; Tapiolas, D.M.; Motti, C.A.; Ovenden, S.P.B.; Kearns, P.S.; Liptrot, C.H. Detailed NMR, including 1,1-ADEQUATE, and anticancer studies of compounds from the echinoderm Colobometra perspinosa. Mar. Drugs 2009, 7, 565-575.

Samples Availability: Available from the authors.

(C) 2010 by the authors; licensee MDPI, Basel, Switzerland. This article is an Open Access article distributed under the terms and conditions of the Creative Commons Attribution license (http://creativecommons.org/licenses/by/3.0/). 